\title{
Grafting for Disease Resistance
}

\author{
Stephen R. King ${ }^{1}$ \\ Vegetable \& Fruit Improvement Center, Department of Horticultural Sciences, \\ Texas A\&M University, College Station, TX 77843-2133
}

\author{
Angela R. Davis \\ USDA, ARS, SCARL, P.O. Box 159, Highway 3 West, Lane, OK 74555 \\ Wenge Liu \\ Chinese Academy of Agricultural Sciences, Zhngzhou, China
}

\begin{abstract}
Amnon Levi
USDA, ARS, U.S. Vegetable Laboratory, 2700 Savannah Highway, Charleston, SC 29414

Additional index words. methyl bromide alternatives, cucumber, melon, watermelon, tomato, eggplant, rootstock
\end{abstract}

\begin{abstract}
The primary purpose of grafting vegetables worldwide has been to provide resistance to soilborne diseases. The potential loss of methyl bromide as a soil fumigant combined with pathogen resistance to commonly used pesticides will make resistance to soilborne pathogens even more important in the future. The major disease problems addressed by grafting include fusarium wilt, bacterial wilt, verticillium wilt, monosporascus root rot, and nematodes. Grafting has also been shown in some instances to increase tolerance to foliar fungal diseases, viruses, and insects. If the area devoted to grafting increases in the future, there will likely be a shift in the soil microbial environment that could lead to the development of new diseases or changes in the pathogen population of current diseases. This shift in pathogen populations could lead to the development of new diseases or the re-emergence of previously controlled diseases. Although grafting has been demonstrated to control many common diseases, the ultimate success will likely depend on how well we monitor for changes in pathogen populations and other unexpected consequences.
\end{abstract}

Grafting vegetable crops is a common practice in Asia and parts of Europe. It was initially introduced to control fusarium wilt in watermelon (Murata and Ohara, 1936), but its use has expanded to include a variety of diseases on cucurbit and solanaceous crops (Table 1). Despite the various crops and long list of diseases controlled, grafting has not yet gained widespread acceptance in the United States. The reasons for the lack of adoption of grafting in the United States may be the result of several factors, including perception of unproven technology, more extensive farming operations, methyl bromide exemptions, and perceived costs associated with grafting. However, it is likely that the use of this technology will increase in the United States as growers become more aware of the benefits of grafting, and researchers should be prepared to anticipate the challenges that are likely to result from increased grafting acreages in the future.

\section{DISEASES CONTROLLED BY GRAFTING}

The most common disease controlled by grafting appears to be fusarium wilt on cucurbit crops caused by various pathovars of Fusarium oxysporum Schltdl., but the list of diseases that

\footnotetext{
This work was partially supported by USDA CSREES \#2006-34402-17121, "Designing Foods for Health".

Mention of a trademark, proprietary product, or vendor does not constitute a guarantee or warranty of the product by Texas A \& M University or the U.S. Dept. of Agriculture and does not imply its approval to the exclusion of other products or vendors that may also be suitable.

${ }^{1}$ To whom reprint requests should be addressed; e-mail srking@tamu.edu
}

are shown to be reduced by grafting has become quite extensive (Table 1). The most common rootstocks for cucurbit crops include Lagenaria siceraria (Molina) Standl. and Cucurbita moshata (Duchesne ex. Poir) $\times C$. maxima (Duchense ex. Lam.) hybrids, both of which are highly resistant to the common pathovars of $F$. oxysporum affecting these crops. Fusarium wilt can also be controlled on tomato (Lycopersicon esculentum Mill.) with resistant rootstocks (Harrison and Burgess, 1962), and because of the compatibility of tomato rootstocks with other solanaceous crops, fusarium wilt in these other crops would likely be controlled by grafting.

Verticillium dahliae Kleb. is another common soilborne pathogen that can be effectively controlled by grafting, although the results appear to sometimes be more variable than for fusarium control; combining grafting with other control measures such as soil sterilization can improve reliability (Ioannou, 2001). Eggplant (Solanum melongena L.) is commonly grafted to control Verticillium wilt, but control has also been demonstrated in tomato, cucumber (Cucumis sativus L.), melon (Cucumis melo L.), and watermelon [Citrullus lanatus (Thunb.) Matsum. and Nakai] (Bletsos, 2005; Paplomatas et al., 2002; Tsror and Nachmias, 1995).

Bacterial wilt of tomato caused by Ralstonia solanacearum (Smith) Yabuuchi et al. can be a devastating disease that has few control alternatives. Methyl bromide has not proven effective for control of bacterial wilt because of high recolonization rates, and alternative soil fumigants such as TeloneC35 (1,3-dichloropropene and chloropicrin; Dow AgroSciences LLC, Indianapolis, IN) and chloropicrin (Arvesta Corp., San Francisco, CA) have little efficacy in controlling the disease (Driver and Louws, 2002).
Actigard (acibenzolar-s-methyl; Syngenta Crop Protection, Greensboro, NC) has shown to be effective, but only when inoculum densities are low (Anith et al., 2004). Host plant resistance in tomato is quantitative, strongly influenced by the environment, and difficult to breed for (Scott et al., 2005) as evidenced by the lack of resistant commercial varieties in many regions where the disease is a major constraint. As with fusarium resistance, grafting has proven to be very effective at controlling bacterial wilt in tomato (Grimault and Prior, 1994).

In melon, fusarium wilt has traditionally been controlled by host plant resistance, which proved very effective until the appearance of $F$. oxysporum f. sp. melonis (Leach \& Currence) W.C. Snyder \& H.M. Hans. race 1,2 . Grafting is now advocated as an effective control for this new race of $F$. oxysporum, at least until new cultivars become available (Trionfetti Nisini et al., 2002). Unlike fusarium wilt in melon, monosporascus vine decline, caused by the soilborne pathogen Monosporascus cannonballus Pollack \& Uecker, has proven difficult to control using host plant resistance. Grafting has proven effective for controlling monosporascus vine decline, although results are sometimes variable (Edelstein et al., 1999). It was found that the rootstocks used to control monosporascus vine decline were not resistant to the fungus but were vigorous enough to allow for crop development in the presence of the pathogen. It was also found that the time of year influenced the level of resistance with a higher level of resistance obtained in spring plantings compared with fall (Cohen et al., 2005). This could explain the variable grafting results, and integrated control methodologies are recommended along with grafting to prevent a buildup of the pathogen, which 
Table 1. A list of crops and diseases reported to be controlled by grafting.

\begin{tabular}{llll}
\hline Crop & \multicolumn{1}{c}{ Disease } & \multicolumn{1}{c}{ Organism } & Reference \\
\hline Cucumber & Fusarium wilt & Fusarium oxysporum & Pavlou et al., 2002 \\
& Phytopthora blight & Phytopthora capsici & Wang et al., 2004 \\
& Root-knot nematodes & Meloidogyne spp. & Giannakou and Karpouzas, 2003 \\
& Verticillium wilt & Verticillium dahliae & Hazama et al., 1993 \\
& Target leaf spot & Corynespora cassicola & Wiggell and Simpson, 1969 \\
Black root rot & Phomopsis sclerotiodes & Bletsos, 2005 \\
& Fusarium wilt & Fusarium oxysporum & Cohen et al., 2000 \\
& Vine decline & Monosporascus cannonballus & Siguenza et al., 2005 \\
& Root-knot nematodes & Meloidogyne spp. & Crinò et al., 2007 \\
& Gummy stem blight & Didymela bryoniae & Alabouvette et al., 1974 \\
& Verticillium wilt & Verticillium dahliae & Alabouvette et al., 1974 \\
Bucurbita sp. & Black root rot & Phomopsis sclerotiodes & Edelstein et al., 2000 \\
Watermelon & Spider mites & Tetranychus cinnabarinus & Murata and Ohara, 1936 \\
& Fusarium wilt & Fusarium oxysporum & Maroto-Borrego and Miguel, 1996 \\
& Root-knot nematodes & Meloidogyne spp. & Paplomatas et al., 2002 \\
Eggplant & Verticillium wilt & Verticillium dahliae & Wang et al., 2002 \\
& Virus complexes & CMV, ZYMV, PRSV, WMV-II & Bletsos et al., 2003 \\
& Verticillium wilt & Verticillium dahliae & Ioannou, 2001 \\
Tomato & Corky root & Pyrenochaeta lycopersici & Ioannou, 2001 \\
& Root-knot nematodes & Meloidogyne spp. & Grimault and Prior, 1994 \\
& Bacterial wilt & Ralstonia solanacearum & Harrison and Burgess, 1962 \\
& Fusarium wilt & Fusarium oxysporum & Bradley, 1968 \\
& Corky root & Pyrenochaeta lycopersici & Ioannou, 2001 \\
& Root-knot nematodes & Meloidogyne spp. & Paplomatas et al., 2002 \\
& Verticillium wilt & Verticillium dahliae & Rivero et al., 2003
\end{tabular}

CMV, Cucumber Mosaic Virus; ZYMV, Zucchini Yellows Mosaic Virus; PRSV, Papaya Ringspot Virus; WMV-II, Watermelon Mosaic Virus II.

may overcome the control afforded by grafting (Cohen et al., 2000).

Wang et al. (2004) found a significant increase in survival and yield of cucumber grafted onto L. siceraria, C. moschata, and Benincasa hispida (Thunb.) Cogn. when inoculated with Phytophthora capsici Leonian and $F$. oxysporum, although it was unclear how much of the improvement was the result of resistance to $P$. capsici; it was apparent that the grafted plants were able to tolerate the fungus better than the nongrafted plants.

Improved control of black root rot (Phomopsis sclerotioides Kesteren) in melon and cucumber has been demonstrated in grafted plants compared with nongrafted controls (Alabouvette et al., 1974; Wiggell and Simpson, 1969).

Improved resistance to root-knot nematodes has also been demonstrated by grafting. Giannakou and Karpouzas (2003) found grafted cucumbers grown in Greece to be resistant to root-knot nematodes, and MarotoBorrego and Miguel (1996) found similar results for watermelon grown in Spain. Ioannou (2001) found that control of root-knot nematodes in eggplant and tomato could be obtained using resistant rootstock, although the resistance did break down under high temperatures, a phenomenon known to occur with the $M i$ gene (Dropkin, 1969). It is probable that tomato and eggplant rootstocks developed with the $\mathrm{Mi}-3$ gene for nematode resistance would be useful for conditions where soil temperatures exceed $30^{\circ} \mathrm{C}$.

There are at least two reports in the literature of increased tolerance to viruses when scions are grafted onto vigorous rootstocks. Wang et al. (2002) reported an increased tolerance in seedless watermelons to virus complexes, presumed to include
Cucumber Mosaic Virus (CMV), Watermelon Mosaic Virus II (WMV-II), Zucchini Yellows Mosaic Virus (PRSV), or Zucchini Yellows Mosaic Virus (ZYMV). Increased tolerance to tomato yellow leaf curl has also been reported on grafted tomato plants (Rivero et al., 2003). It is presumed in each case that the resistance is the result of increased vigor provided by the rootstock, which allows the scion to continue to grow in the presence of the virus.

There is at least one report in the literature of transferred insect control from the rootstock to the scion. Edelstein et al. (2000) were able to transfer spider mite (Tetranychus cinnabarinus Boisd.) control from a resistant $L$. siceraria to spider mite-susceptible $C$. maxima. However, they were not able to transfer spider mite resistance to a susceptible melon through grafting.

\section{MECHANISMS OF DISEASE CONTROL BY GRAFTING}

The method of disease control afforded by grafting is not well understood. It is presumed that the primary method is by avoidance when the rootstock is resistant to the pathogen. This has been confirmed by observations in which suckers or other intact roots from the scion confer susceptibility to the grafted plant. However, Lee (1994) noted that dualrooted grafted plants often exhibit resistance almost as good as those only having roots from the rootstock. This may be related to the resistance reported to monosporascus vine decline in melon, in which the rootstock does not have resistance, but the increased vigor from the rootstock allows the plant to develop despite the pathogen (Cohen et al., 2000). This increase in vigor may also explain resistance to foliar pathogens, especially viruses. In the case of bacterial wilt resistance, it has been shown that resistant rootstocks physically limit the movement of bacteria from the soil to the scion (Grimault et al., 1994); it was later shown that when the resistant rootstock was used as the scion to graft onto susceptible rootstock, the resistant plant succumbed to the disease (Obrero et al., 1971). It would appear that in most cases of resistance, substances translocated from the rootstock to the scion are not a factor, although translocation is known to occur (Lee, 1994), and may be the mechanism responsible for resistance to spider mites shown to transmit from $L$. siceraria to $C$. maxima (Edelstein et al., 2000).

\section{CURRENT DISEASE CONTROL IN THE UNITED STATES}

Vegetable production in the United States is much more extensive than in other parts of the world such as Asia and Europe. Because of this, crop rotation, even fallowing land for extensive periods, has been feasible. Crop rotations have proven to be an effective strategy to control many soilborne diseases, but because most of these pathogens can survive for a long period of time, the effectiveness of crop rotation is limited once a disease outbreak occurs. Because of the long survival rate of pathogens in the soil and because of increased urbanization and reduced water resources, it is likely that vegetable farming will become more intensive in the United States in the future.

An effective control strategy for soilborne diseases in the past has been the use of methyl bromide as a soil fumigant. Europe began to adopt grafting as part of an integrated approach to replace methyl bromide, and grafting is now in widespread use in countries 
of the Mediterranean Basin. In the United States, however, grafting has not been viewed as a viable alternative. Methyl bromide had been used extensively in the United States and Europe to control soilborne diseases before the international phase-out, which began in 1999 leading to a complete phaseout in 2005, except for allowable critical use exemptions. In fact, critical use exemptions have been granted for using methyl bromide on cucurbit crops, eggplant, peppers, and tomatoes in various regions of the United States every year since 2005 . To be granted a critical use exemption, alternatives must not be technically feasible or economically viable. One of the primary reasons stated on the request for exemption in 2008 was: "There are no studies documenting the commercial availability of resistant rootstock immune to the fungal pathogens listed as major cucurbit pests. Grafting and plant breeding are thus also rendered technically infeasible as methyl bromide alternatives for control of Phytophthora and Fusarium fungi" (Thompson, 2007). As previously stated, grafting can sometimes be a solution on its own for soilborne diseases and can often be part of an integrated solution. Some researchers have even found grafting to be an advantage over methyl bromide as a result of comparable disease resistance, reduced environmental impact, improved performance in addition to disease resistance and reduced cost (Miguel et al., 2004).

The perceived cost may be the major factor limiting grafting in the United States. The Environmental Protection Agency web site on methyl bromide alternatives lists the costs of grafting vegetables as ranging between $\$ 1.80$ and $\$ 2.28$ per plant and the cost of methyl bromide fumigation is listed as $\$ 0.41$ to 0.92 per plant, but the references date to at least 1992 and 1996 (U.S. Environmental Protection Agency, 2007). The cost of grafting vegetables has decreased dramatically since the mid-1990s; estimates now run $\$ 1.00$ or less per plant for watermelon in south Texas (Speedling, Inc., Alamo, TX, personal communication), and the costs of fumigating with methyl bromide are likely much higher now than in 1996. It would appear that grafting, as demonstrated in Asia and much of Europe, is a viable alternative to methyl bromide for disease control in the United States.

\section{CONCLUSIONS}

If grafting becomes a common production practice for cucurbit and solanaceous crops in the United States, researchers should be prepared to monitor for changes in pathogen populations that may result in the emergence of a new disease or a previously controlled disease. It has been reported that in Japan, the original rootstock for watermelon used to control fusarium wilt began to break down beginning in the 1950s. The causal organism was reported to be $F$. oxysporum f. sp. lagenariae Matuo \& Yamamoto. Breeding for resistance to this new $F$. oxysporum pathotype followed so that most rootstocks today are resistant (Sakata et al., 2003). However, one would expect that new races or pathotypes will probably evolve in response to selection pressure caused by widespread use of rootstocks. One advantage afforded by grafting is that rootstocks can be rotated between not just different varieties, but also different species, which should result in a reduced selection pressure for new pathotypes able to overcome resistance. It is also possible that certain diseases affecting the scion may become more prevalent with the use of grafting. Boubourakas et al. (2004) detected cucumber green mottle mosaic virus on grafted watermelon, whereas nongrafted watermelon were unaffected by the disease. Although this association has not been repeated, it highlights the necessity for monitoring for new disease developments when production practices change dramatically, as would be the case if farming practices shift extensively to grafted plants. These changes can likely be mitigated by rotating the rootstocks among different species if possible, continued breeding for resistance in the rootstock, and extensive monitoring for new pest outbreaks in grafted plants.

\section{Literature Cited}

Alabouvette, C., F. Rouxel, J. Louvet, P. Bremeersch, and M. Mention. 1974. Recherche d'un portegreffe resistant au Phomopsis sclerotioides et au Verticillium dahliae pour la culture du melon et du concombre en serre. Pepinieristes Hort. Maraichers. 152:19-24.

Anith, K.N., M.T. Momol, J.W. Kloepper, J.J. Marois, S.M. Olson, and J.B. Jones. 2004. Efficacy of plant growth-promoting rhizobacteria, acibenzolar-s-methyl, and soil amendment for integrated management of bacterial wilt on tomato. Plant Dis. 88:669-673.

Bletsos, F.A. 2005. Use of grafting and calcium cyanamide as alternatives to methyl bromide soil fumigation and their effects on growth, yield, quality and Fusarium wilt control in melon. J. Phytopathol. 153:155161.

Bletsos, F., C. Thanassoulopoulos, and D. Roupakias. 2003. Effect of grafting on growth, yield, and Verticillium wilt of eggplant. HortScience 38: 183-186.

Boubourakas, I.N., E. Harziloukas, Y. Antignus, and N.I. Katis. 2004. Etiology of leaf chlorosis and deterioration of the fruit interior of watermelon plants. J. Phytopathol. 152:580 588.

Cohen, R., Y. Burger, C. Horev, A. Porat, and M. Edelstein. 2005. Performance of galiatype melons grafted on $\mathrm{t}$ Cucurbita rootstock in Monosporascus cannonballus-infested soils. Ann. Appl. Biol. 146:381-387.

Cohen, R., S. Pivonia, Y. Burger, M. Edelstein, A. Gamliel, and J. Katan. 2000. Toward integrated management of Monosporascus wilt of melons in Israel. Plant Dis. 84:496-505.

Crinò, P., C.L. Bianco, Y. Rouphael, G. Colla, F. Saccardo, and A. Paratore. 2007. Evaluation of rootstock resistance to Fusarium wilt and gummy stem blight and effect on yield and quality of grafted 'Inodorus' melon. Hort Science 42:521-525.

Driver, J. and F.J. Louws. 2002. Fumigants and varieties to manage southern bacterial wilt of tomato. 2002 Annual International Research
Conference on Methyl Bromide Alternatives and Emissions Reductions. Orlando, FL.

Dropkin, V.H. 1969. The necrotic reaction of tomatoes and other hosts resistant to Meloidogyne: Reversal by temperature. Phytopathology 59:1632-1637.

Edelstein, M., R. Cohen, Y. Burger, S. Shriber, S. Pivonia, and D. Shtienberg. 1999. Integrated management of sudden wilt in melons, caused by Monosporascus cannonballus, using grafting and reduced rates of methyl bromide. Plant Dis. 83:1142-1145.

Edelstein, M., Y. Tadmor, F. Abo-Moch, Z. Karchi, and F. Mansour. 2000. The potential of Lagenaria rootstock to confer resistance to the carmine spider mite, Tetranychus cinnabarinus (Acari: Tetranychidae) in Cucurbitaceae. Bull. Entomol. Res. 90:113-117.

Giannakou, I.O. and D.G. Karpouzas. 2003. Evaluation of chemical and integrated strategies as alternatives to methyl bromide for the control of root-knot nematodes in Greece. Pest Mgt. Sci. 59:883-892.

Grimault, V., B. Gelie, M. Lemattre, P. Prior, and J. Schmit. 1994. Comparative histology of resistant and susceptible tomato cultivars infected by Pseudomonas solanacearum. Physiol. Mol. Plant Pathol. 44:105-123.

Grimault, V. and P. Prior. 1994. Grafting tomato cultivars resistant or susceptible to bacterial wiltanalysis of resistance mechanisms. J. Phytopathol.-Phytopathologische Zeitschrift. 141:330334.

Harrison, D.J. and P.G. Burgess. 1962. Use of rootstock resistance for controlling Fusarium wilt of tomatoes. Plant Pathol. 11:23-25.

Hazama, W., S. Morita, and T. Kato. 1993. Resistance to Corynespora target leaf spot in cucumber grafted on a bloomless rootstock [in Japanese with English summary]. Ann Phytopath. Soc. Japan. 59:243-248.

Ioannou, N. 2001. Integrating soil solarization with grafting on resistant rootstocks for management of soil-borne pathogens of eggplant. J. Hort. Sci. Biotechnol. 76:396-401.

Lee, J.M. 1994. Cultivation of grafted vegetables. I. Current status, grafting methods and benefits. HortScience 29:235-239.

Maroto-Borrego, J.V. and A. Miguel. 1996. El injerto herbáceo en la sandia (Citrullus lanatus) como alternativa a la desinfección química del suelo. Investigación Agraria. Producción y Protección Vegetales 11:239-253.

Miguel, A., J.V. Maroto, A. San Bautista, C. Baixauli, V. Cebolla, B. Pascual, S. Lopez, and J.L. Guardiola. 2004. The grafting of triploid watermelon is an advantageous alternative to soil fumigation by methyl bromide for control of Fusarium wilt. Sci. Hort. 103:9-17.

Murata, J. and K. Ohara. 1936. Prevention of watermelon fusarium wilt by grafting Lagenaria [in Japanese]. Jpn. J. Phytopathol. 6:183-189.

Obrero, F.P., M. Aragaki, and E.E. Trujillo. 1971. Tomato bacterial wilt-inoculation of susceptible scions grafted to resistant rootstock. Plant Disease Reporter. 55:521-522.

Paplomatas, E.J., K. Elena, A. Tsagkarakou, and A. Perdikaris. 2002. Control of Verticillium wilt of tomato and cucurbits through grafting of commercial varieties on resistant rootstocks. Acta Horticulturae. Proceedings of the Second Balkan Symposium on Vegetables and Potatoes, Thessaloniki, Greece, $11-15$ Oct. 2000. 579:281-284.

Pavlou, G.C., D.J. Vaklounakis, and E.K. Ligoxigakis. 2002. Control of root and stem rot of cucumber, caused by Fusarium oxysporum f. sp. Radicis-cucumerinum, by grafting 
onto resistant rootstocks. Plant Dis. 86:379382.

Rivero, R.M., J.M. Ruiz, and L. Romero. 2003. Role of grafting in horticultural plants under stress conditions. J. Food, Agr. \& Environ. 1: 70-74.

Sakata, Y., T. Ohara, and M. Sugiyama. 2003. The history and present state of grafting of cucurbitaceous vegetables in Japan. Acta Hort. 731:159-170.

Scott, J.W., J.F. Wang, and P.M. Hanson. 2005. Breeding tomatoes for resistance to bacterial wilt, a global view. I International Symposium on Tomato Diseases, 25 Nov., Orlando, FL.

Siguenza, C., M. Schochow, T. Turini, and A. Ploeg. 2005. Use of Cucumis metuliferus as a rootstock for melon to manage Meloidogyne incognita. J. Nematol. 37:276-280.

Thompson, J.E. 2007. Methyl bromide critical use nomination for preplant soil use for cucurbits grown in open fields. US EPA Ozone Layer Depletion-regulatory programs web site. 22 Jan. $2008<$ http://www.epa.gov/ozone/mbr/ CUN2008/CUN2008_Cucurbits.pdf>.

Trionfetti Nisini, P., G. Colla, E. Granati, O. Temperini, P. Crinò, and F. Saccardo. 2002. Rootstock resistance to Fusarium wilt and effect on fruit yield and quality of two muskmelon cultivars. Sci. Hort. 93:281-288.

Tsror, L. and A. Nachmias. 1995. Significance of the root system in Verticillium wilt tolerance in potato and resistance in tomato. Isr. J. Plant Sci. 43:315-323.
U.S. Environmental Protection Agency. 2007. Plant grafting as a tool to help reduce the need for soil fumigation with methyl bromide. 22 Jan. $2008<$ http://www.epa.gov/spdpublc/mbr/ casestudies/volume3/graftng3.html $>$.

Wang, H.R., S.J. Ru, L.P. Wang, and Z.M. Feng. 2004. Study on the control of Fusarium wilt and phytophthora blight in cucumber by grafting. Acta Agriculturae Zhejiangensis 16:336339.

Wang, J., D.W. Zhang, and Q. Fang. 2002. Studies on antivirus disease mechanism of grafted seedless watermelon. Journal of Anhui Agricultural University. 29:336-339.

Wiggell, P. and C.J. Simpson. 1969. Observations on the control of Phomopsis root rot of cucumber. Plant Pathol. 18:71-77. 